\title{
Population biology and reproduction of the hermit crab Clibanarius vittatus (Decapoda: Anomura) in an estuarine region of southern Brazil
}

\author{
BRUNO SAMPAIO SANT'ANNA ${ }^{1,2,3}$, ÁLVARO LUIZ DIOGO REIGADA ${ }^{1,2}$ \\ AND MARCELO ANTONIO AMARO PINHEIRO ${ }^{1}$ \\ ${ }^{1}$ Research Group in Crustacean Biology (Crusta), Universidade Estadual Paulista (UNESP), Campus Experimental do Litoral \\ Paulista (CLP), Praça Infante D. Henrique, s/n-Parque Bitarú, CEP 11330-90o-São Vicente (São Paulo), Brazil, ${ }^{2}$ Universidade \\ Estadual Paulista (UNESP), Campus de Rio Claro-Instituto de Biociências-Programa de Pós-Graduação em Zoologia, \\ ${ }^{3}$ Unimes-Universidade Metropolitana de Santos
}

\begin{abstract}
The population dynamics and reproduction of the hermit crab Clibanarius vittatus were evaluated on Pescadores Beach, located on the estuarine channel of São Vicente (São Paulo), Brazil. The hermit crabs were captured by hand during low tide, from May 2001 to April 2003. A total of 2554 hermit crabs were captured, of which 701 were males, 1741 non-ovigerous females, 48 ovigerous females and 64 intersex individuals. The size-frequency distribution of the males was represented by a platykurtic bell-shaped curve, which differed from the leptokurtic bell-shaped curve of the females. The smaller and intermediate classes were composed mainly of females (modal size 6.5-7.5 $\mathrm{mm}$ carapace shield length (CSL)), and the larger classes only by males (modal size 9.5-10.5 mm CSL). The overall sex-ratio was skewed toward females (o.39:1/M:F), differing significantly from the expected 1:1. A seasonal reproductive pattern was recorded for $\mathrm{C}$. vittatus in this location, with more intensive reproductive activity in the warmer months. The absence of juveniles suggests that their recruitment area is different than the area inhabited by adults, possibly another area with more protection and specialized or different resources for young.
\end{abstract}

Keywords: hermit crab, Clibanarius vittatus, reproduction, population biology

Submitted 9 July 2008; accepted 12 September 2008

\section{INTRDDUCTION}

Studies of animal populations are essential to understand the dynamics of ecosystems. Generally, population analyses have focused on descriptions of density, size-structure, sex-ratio and breeding periods that can be compared to other populations of the same species, genus or other taxonomic levels (Litulo, 2005a). Although hermit crabs are not likely to be of commercial importance, they contribute to the mass of planktonic organisms in coastal waters that help to feed the young of commercial species (Squires et al., 2001), and they are an important part of the trophic chain, mainly where their populations are largest.

In crustaceans, the reproductive cycle is influenced by biotic and abiotic factors that rule the larval, gonadal and embryonic development (Mantelatto \& Garcia, 1999; Bertini et al., 2004). The breeding season may vary between populations in response to the influence of environmental factors in a given area (Litulo, 2005b). Sastry (1983) proposed two reproductive patterns for crustaceans: (1) continuous reproduction, when ovigerous females occur uniformly throughout

Corresponding author:

B.S. Sant'Anna

Email: brunusant@hotmail.com the year; or (2) seasonal reproduction, with peaks in some months, with ovigerous females occurring only in some months of the year.

In hermit crabs, four aspects of reproduction have been studied: (1) frequency of ovigerous females by months or seasons (Manjón-Cabeza \& Garcia-Raso, 1995; Martinelli et al., 2002; Litulo 2005 a, b); (2) analysis of fecundity (Mantelatto \& Garcia, 1999; Turra \& Leite, 1999; Negreiros-Fransozo et al., 1992; Litulo, 2005c); (3) macroscopic analysis of the gonads (only by Bertini et al., 2004); and (4) histology of gonads (Manjón-Cabeza \& García-Raso, 2000a, b).

The hermit crab Clibanarius vittatus (Bosc, 1802) is the most abundant in the intertidal zone of the São Vicente Estuary. According to Melo (1999), this species lives in estuarine areas, coral reefs and sandy substrates, in shallow waters up to $22 \mathrm{~m}$ deep. Studies have treated its population biology and reproduction (Kicher, 1967); larval and juvenile development (Young \& Hazlett, 1978; Brossi-Garcia, 1988, respectively); and other reproduction and population analysis (Fotheringham, 1975; Lowery \& Nelson, 1988; Reigada \& Santos, 1997; Turra \& Leite, 2000, 2001; and Hazlett et al., 2005). In these studies, the reproductive period was determined by the frequency of ovigerous females during the year, a common method used to study the reproduction of pleocyemata crustaceans. 
This study aimed to analyse the population structure (sizes of sexes, seasonal size-frequency distribution and sex-ratio) of the hermit crab C. vittatus in the estuarine region of São Vicente, state of São Paulo, Brazil, and the reproductive period based on the occurrence of ovigerous females during the seasons, compared to the frequency of gonad maturation stages.

\section{MATERIALS AND METHODS}

The study was conducted in the intertidal zone of Pescadores Beach $\left(23^{\circ} 58^{\prime} 21^{\prime \prime} \mathrm{S}-46^{\circ} 23^{\prime} 35^{\prime \prime} \mathrm{W}\right.$ : Figure 1), located on the estuarine channel of São Vicente (São Paulo), Brazil, which shelters a diverse marine fauna, including intertidal molluscs, macroalgae and benthic crustaceans (Sant'Anna et al., 2006).

The hermit crabs were captured by hand during low tide, from May 2001 to April 2003. Monthly captures were made by two people, with a standard capture effort of 10 minutes. Water temperature $\left({ }^{\circ} \mathrm{C}\right)$ was measured monthly. The hermit crabs were stored frozen. For analysis, the specimens were defrosted and removed from their gastropod shells, for identification according to Melo (1999). The carapace shield length (CSL) was recorded from the tip of the rostrum to the midpoint of the cervical groove, using a Vernier caliper $(0.01 \mathrm{~mm})$. For the size-frequency distribution analysis,

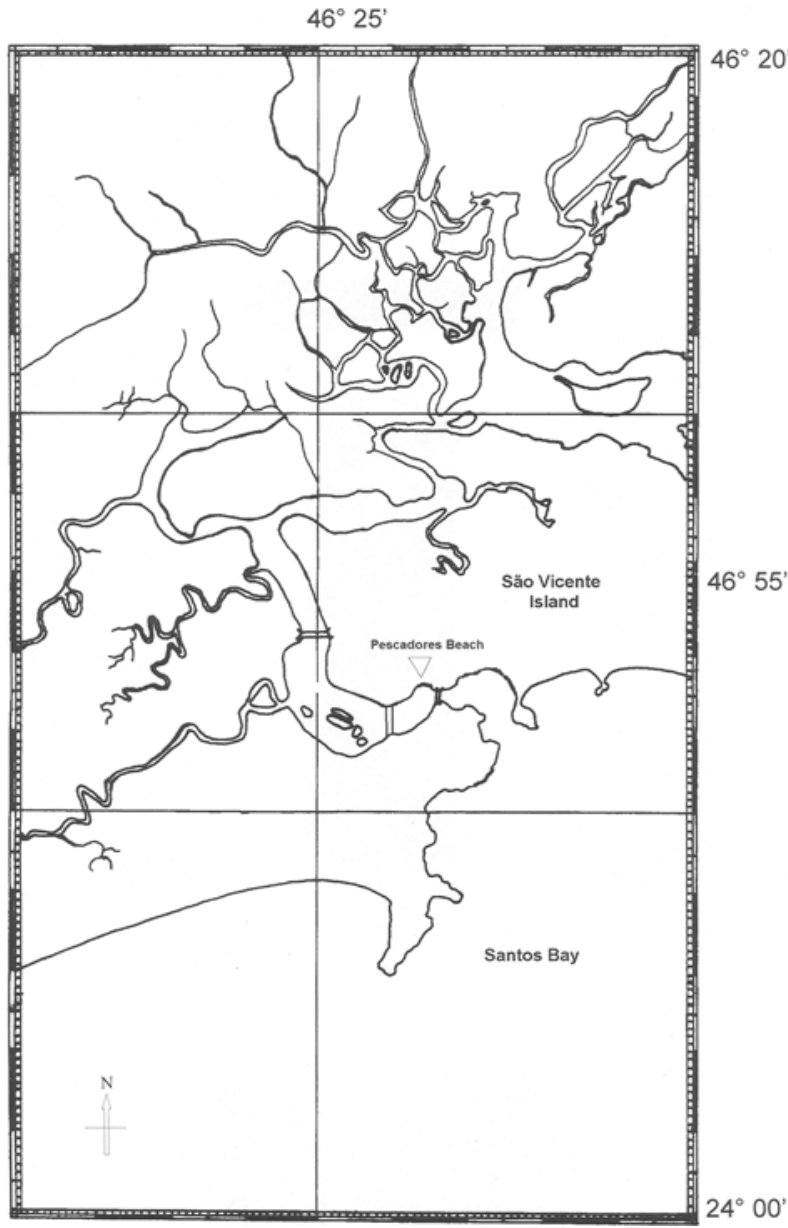

Fig. 1. Estuary of São Vicente (São Paulo), Brazil, showing the location of Pescadores Beach (setae). size-class intervals of $1 \mathrm{~mm}$ of CSL were used. The size intervals of each class were determined according to the mathematical formula of Sturges (1926). After identification and biometric analysis, the sex of each individual was determined from the position of the gonopores and the presence of eggs, and four population categories were established: (1) males, with gonopores on the basis of the fifth pereopods; (2) nonovigerous females, with gonopores on the basis of the third pereopods; (3) intersex individuals, with gonopores on the bases of both the third and fifth pereopods; and (4) ovigerous females. Individuals of uncertain sex and intersex individuals were not included in the statistical analyses of population and reproduction.

All the individuals were dissected to observe the stage of gonad maturation, and were classified according to three gonad stages determined for males (immature or rudimentary gonads, which are undifferentiated or thin and translucent with two small white ducts; developing, with an initial winding, pale or white filament; and developed, with a strongly coiled testis with the dominant visible organ pale white and a white vas deferens), and females (immature or rudimentary, with ovaries as two fine, wine-coloured filaments; developing, with ovarian maturation beginning and represented by two wine-coloured filaments, occupying a large volume in the abdomen; and developed, when ovaries are dark-wine-coloured and fill the abdomen). The reproductive period was determined by the percentage of individuals of the same sex with developed gonads and the monthly incidence of ovigerous females during the course of the sampling period.

The normality of the size-frequency distribution was tested by the Kolmogorov-Smirnov (KS) test for each population category, and the size of individuals was compared by the Kruskal-Wallis test. The monthly and overall sex ratios (M:F) were tested with the Chi-square test $\left(\chi^{2}\right)$. The relationship of sex-ratio to size-class was fitted only for classes with more than ten individuals, as recommended by Wenner (1972). The correlation of water temperature $\left({ }^{\circ} \mathrm{C}\right)$ and the incidence of individuals with developed gonads were tested by Spearman's correlation. A significance level of $5 \%$ was adopted for all statistical analyses (Sokal \& Rohlf, 1995).

\section{RESULTS}

A total of 2554 hermit crabs were captured in the intertidal zone of Pescadores Beach: 701 males, 1741 non-ovigerous females, 48 ovigerous females and 64 intersex individuals. Male individuals were significantly larger than females $(P<0.05)$, but intersex individuals were the same size as males (Table 1).

The overall size-frequency distribution of the population differed from normality $(\mathrm{KS}=0.0755 ; P<0.01)$, with a unimodal distribution. The size-frequency distribution of the males was represented by a platykurtic bell-shaped curve that differed from the leptokurtic bell-shaped curve for females (Figure 2). Although the size-frequency distribution of the population did not show a normal distribution, this was not true for all sexes; the size-frequency distribution for males differed from normality (KS $=0.0791 ; P<0.01$ ), but the size-frequency distributions of non-ovigerous females and ovigerous females showed significant normal distributions $(\mathrm{KS}=0.03 ; P>0.05$ and $\mathrm{KS}=0.1079 ; P>0.05)$. 
Table 1. Number of individuals and size-range (carapace shield length) of the hermit crabs captured on Pescadores Beach. N, number of individuals; Min, minimum; Max maximum; $\mathrm{x}$ mean; SD, standard deviation; $\mathrm{M}$, males; F, non-ovigerous females; OF, ovigerous females; INT, intersex individuals.

\begin{tabular}{lrlrl}
\hline Sex & \multicolumn{1}{c}{ N } & Min & Max & x \pm SD \\
\hline M & 701 & 2.7 & 13.8 & $8.93 \pm 1.81 \mathrm{a}$ \\
F & 1741 & 2.6 & 11.7 & $6.61 \pm 1.14 \mathrm{~b}$ \\
OF & 48 & 4.9 & 9.4 & $6.71 \pm 1.07 \mathrm{~b}$ \\
INT & 64 & 5.4 & 12.3 & $9.37 \pm 1.43 \mathrm{a}$ \\
Total & 2554 & 2.6 & 13.8 & $7.32 \pm 1.74$ \\
\hline
\end{tabular}

Means followed by the same lower-case letter did not show significant differences $(P>0.05)$.

In the same figure, we can observe that the smaller and intermediate classes were composed mainly of females (modal size $6.5-7.5 \mathrm{~mm} \mathrm{CSL}$ ), and the larger classes only of males (modal size $9.5-10.5 \mathrm{~mm} \mathrm{CSL}$ ).

The seasonal size - frequency distribution of the population (Figure 3) showed unimodal and bimodal distributions during the seasons. Few juveniles were recorded in this location, and females were more abundant than males during the two years of the study. Ovigerous females occurred in all seasons of the year, but in lower frequency in the winter. The abundance of females by month is shown in Table 2. The sex ratio (M:F), was nearly always skewed toward females, except in two months of the study period, the overall sex-ratio (0.39:1; M:F) differed significantly from $1: 1 \quad\left(\chi^{2}=475.399 ; P<\right.$ $0.001)$. The sex-ratio related to size, showed an anomalous curve (Figure 4), with females extremely abundant in intermediate size-classes, and males numerically superior in the larger ones.

The percentage of individuals with developed gonads was larger in the warmer months of the year (Figure 5). The percentage of ovigerous females (Figure 6) evidenced a seasonal



Fig. 2. Size-frequency distribution of individuals of Clibanarius vittatus caught on Pescadores Beach, São Vicente Estuary (São Paulo), Brazil CSL, carapace shield length. reproductive pattern at this location, with more intensive reproductive activity in the warmer months. This is supported by a positive correlation between water temperature and females with developed gonads ( $r s=0.61 ; P=0.0017)$. Dissections of the intersex individuals revealed male gonads, with one paired coiled whitish duct.

\section{DISCUSSIDN}

The sexual dimorphism in relation to size observed in the present study is a common aspect of hermit-crab biology, as suggested by several previous reports (Fransozo \& Mantelatto, 1998; Manjón-Cabeza \& García-Razo, 1998; Turra \& Leite, 2000; Mantelatto \& Martinelli, 2001; Branco et al., 2002; Bertini et al., 2004; Macpherson \& Raventos, 2004; Litulo, 2005a, c; Litulo \& Tudge, 2005; Mantelatto et al., 2005). According to Abrams (1988), three factors may influence sexual dimorphism in hermit crabs: (1) the difference of energy available for growth, with less somatic growth in females due to greater expenditure of energy in egg production; (2) the larger reproductive effort exhibited by males, which are able to copulate with more than one female; and (3) the larger dimensions of males, to optimize fertilization of the females and win intraspecific fights.

In this population of C. vittatus in São Vicente Estuary, the differential growth rate between the sexes (as proposed by Abrams, 1988) suggests an important factor for the sexual dimorphism. According to the growth analysis of this same population by Sant'Anna et al. (2008), males have a larger constant growth than do females (males, $K=0.51$; and females, $K=0.40$ ), and the different growth periods of the sexes reduce intraspecific competition for gastropod shells. A slower growth rate of females would be a consequence of utilization of relatively small shells in nature, as suggested by Litulo (2005 a, c) for Dardanus deformis (H. Milne-Edwards, 1836) and Clibanarius longitarsus (De Haan, 1849), respectively.

A few ovigerous females and juveniles were captured during the present study, a result similar to that obtained by Litulo (2005a) for D. deformis in Maputo Bay, Mozambique. The lower abundance of juveniles suggests that the recruitment area is different from the area inhabited by adults, possibly another area with more protection and specialized or different resources for the juveniles. Although there is a good supply of smaller shells of Littorina sp., suitable for juveniles, at Pescadores Beach (personal observation), it is possible that $C$. vittatus ovigerous females migrate to the entrance of the estuary, where their larvae have access to optimum salinities for the first juveniles ( 25 to $35 \%$, according to Young \& Hazlett, 1978), avoiding the wide salinity variations in the study area (20 to $35 \%$, according to Sant'Anna et al., 2006). Thus, when the juvenile hermit crabs return inside the estuary they already measure several millimetres in size. A similar absence of juvenile individuals was noted by Turra \& Leite (2000), who studied three sympatric species of hermit crabs of the genus Clibanarius, on another part of the Brazilian coast. As estimated by these authors, the recruitment period (December to March, according to Sant'Anna et al., 2008) was equivalent to those months when greater reproductive activity was observed in this population.

The sex-ratio of the C. vittatus population in the present study was skewed toward females, with a difference from 

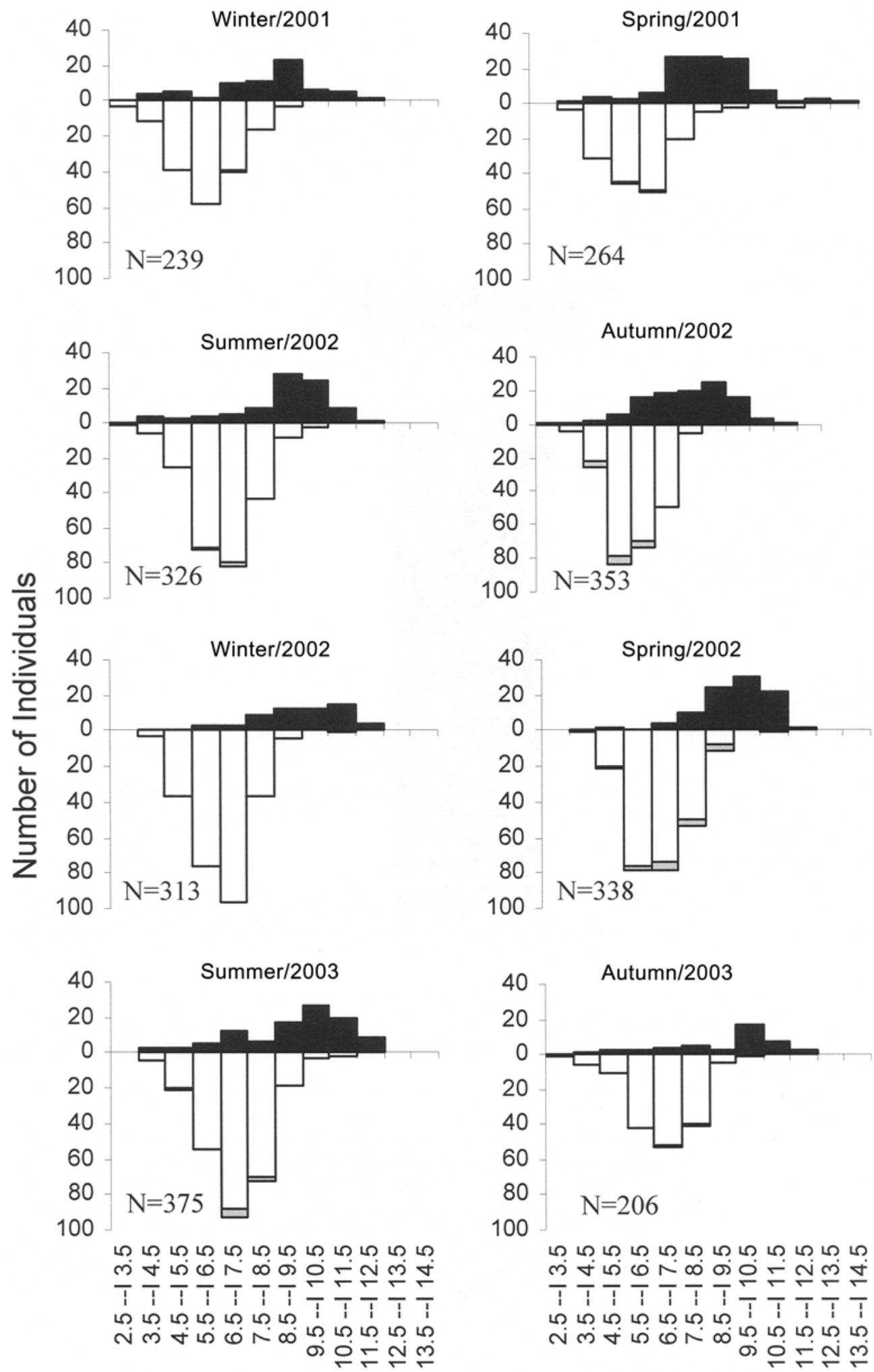

\section{Size Classes (CSL)}

-M $\square \mathrm{F} \quad \square \mathrm{OF}$

Fig. 3. Seasonal size - frequency distribution of individuals of Clibanarius vittatus captured on Pescadores Beach, São Vicente Estuary, Brazil. CSL, carapace shield length. 
Table 2. Sex-ratio by month obtained for the population of hermit crabs Clibanarius vittatus on Pescadores Beach, São Vicente (São Paulo), Brazil.

\begin{tabular}{llrlrl}
\hline Months & Males & Females & Sex-ratio (M:F) & \multicolumn{1}{l}{$\boldsymbol{\chi}^{2}$} & $\boldsymbol{P}$ \\
\hline May 2001 & 27 & 50 & $0.54^{*}$ & 6.87 & 0.0122 \\
June & 24 & 62 & $0.39^{*}$ & 16.79 & 0.0001 \\
July & 18 & 53 & $0.34^{*}$ & 17.25 & 0.0001 \\
August & 26 & 55 & $0.47^{*}$ & 10.38 & 0.0019 \\
September & 67 & 81 & $0.83^{\text {ns }}$ & 1.32 & 0.2853 \\
October & 18 & 25 & $0.72^{\text {ns }}$ & 1.14 & 0.3602 \\
November & 19 & 54 & $0.35^{*}$ & 16.78 & 0.0001 \\
December & 30 & 101 & $0.30^{*}$ & 38.48 & 0.0000 \\
January 2002 & 30 & 49 & $0.61^{*}$ & 4.57 & 0.0429 \\
February & 27 & 89 & $0.30^{*}$ & 33.14 & 0.0000 \\
March & 46 & 84 & $0.55^{*}$ & 8.34 & 0.0054 \\
April & 32 & 97 & $0.33^{*}$ & 32.75 & 0.0000 \\
May & 33 & 61 & $0.54^{*}$ & 8.34 & 0.0054 \\
June & 13 & 63 & $0.21^{*}$ & 32.89 & 0.0000 \\
July & 20 & 71 & $0.28^{*}$ & 28.58 & 0.0000 \\
August & 26 & 120 & $0.22^{*}$ & 60.52 & 0.0000 \\
September & 12 & 32 & $0.37^{*}$ & 9.09 & 0.0042 \\
October & 42 & 125 & $0.34^{*}$ & 41.25 & 0.0000 \\
November & 40 & 87 & $0.46^{*}$ & 17.39 & 0.0000 \\
December & 33 & 117 & $0.28^{*}$ & 47.04 & 0.0000 \\
January 2003 & 38 & 73 & $0.52^{*}$ & 11.04 & 0.0013 \\
February & 34 & 80 & $0.42^{*}$ & 18.56 & 0.0000 \\
March & 11 & 71 & $0.15^{*}$ & 43.90 & 0.0000 \\
April & 35 & 89 & $0.39^{*}$ & 23.52 & 0.0000 \\
\hline n & & & &
\end{tabular}

ns , non-significant; ${ }^{*} P<0.05$.

the expected proportion (1:1). The same has been recorded for various populations of different hermit-crab species around the world (Manjón-Cabeza \& García-Raso, 1998; Benvenuto \& Gherardi, 2001; Macpherson \& Raventos, 2004; Litulo, 2005c; Litulo \& Tudge, 2005) and in two other populations of C. vittatus (Lowery \& Nelson, 1988; Turra \& Leite, 2000). The same pattern was obtained for overall sex-ratio, and as a function of size, showed an anomalous curve pattern according to the classification proposed by Wenner (1972). This author suggested four explanations for this pattern of the

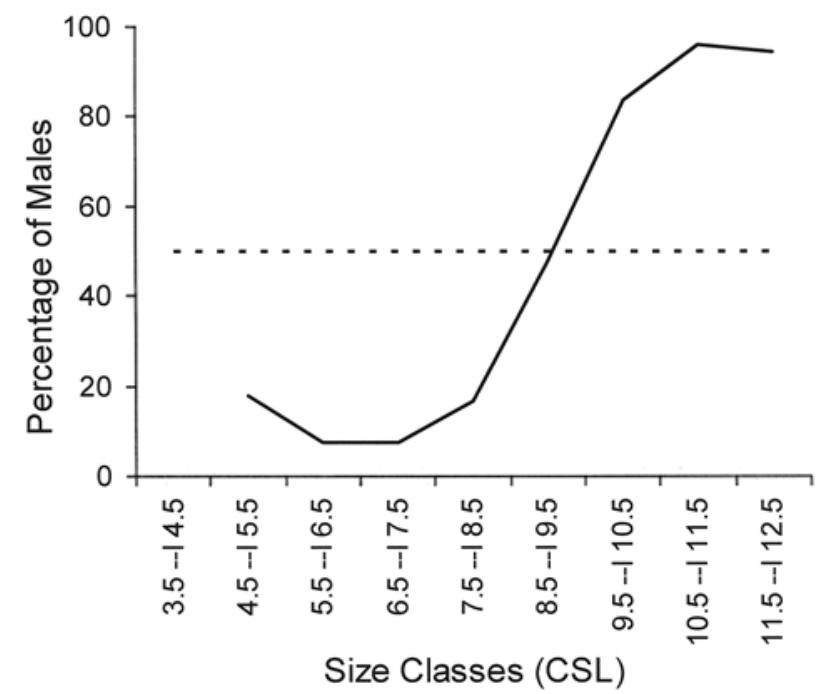

Fig. 4. Percentage (fitted with a mobile mean) of males by size-classes, of Clibanarius vittatus caught on Pescadores Beach, São Vicente Estuary, Brazil. CSL, carapace shield length; horizontal line (- - ) represents the expected sex-ratio (1:1).

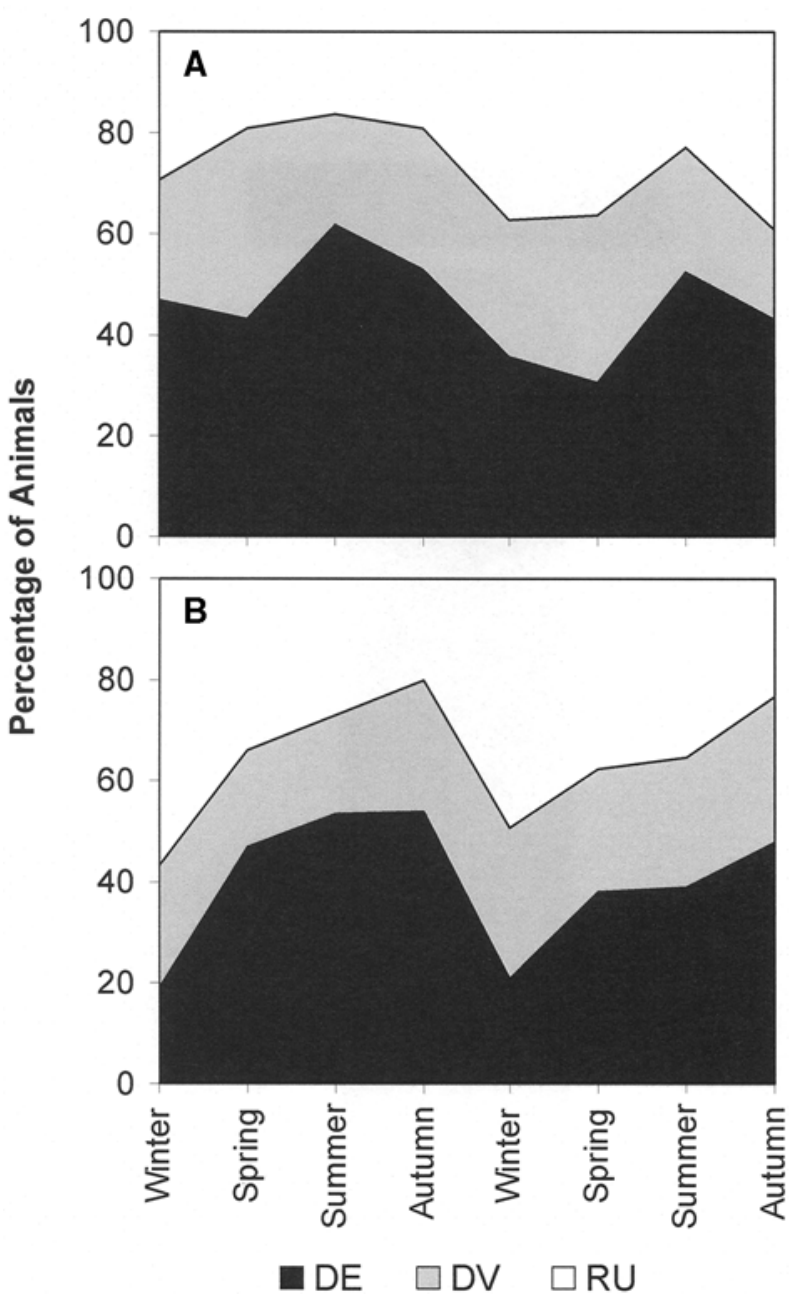

Fig. 5. Seasonal percentage of males (A) and females (B) of Clibanarius vittatus, with rudimentary (RU), developing (DV) and developed (DE) gonads during the study period on Pescadores Beach, São Vicente Estuary, Brazil.

sex-ratio: (1) differences between the sexes in longevity and time for growth; (2) differential migration; (3) different mortality or growth rates between sexes; and (4) sex reversal. In C. vittatus, the most probable causes are the difference in the

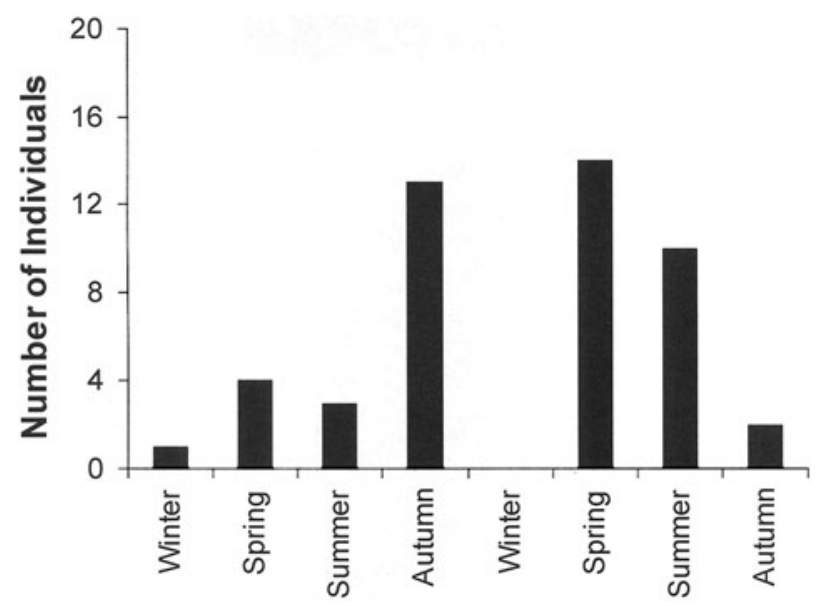

Fig. 6. Seasonal abundance of ovigerous females of Clibanarius vittatus caught during the study period on Pescadores Beach, São Vicente Estuary, Brazil. 
growth rates between the sexes, with an influence of longevity (Sant'Anna et al., 2008) or habitat partitioning as suggested by Turra \& Leite (2000). Sex reversal occurs in a low percentage of C. vittatus populations (see present study and Turra \& Leite, 2000), representing a third and minor cause of the sexratio pattern observed, and there still is no explanation for the mechanism of sex reversal in hermit crabs (Turra \& Leite, 2000; Turra, 2004).

Hermit crabs may have continuous or seasonal reproduction (Manjón-Cabeza \& Garcia-Raso, 1998; Bertini \& Fransozo, 2000; Turra \& Leite, 2000). In this study, the $C$. vittatus population showed a seasonal reproductive pattern with some large peaks of individuals with developed gonads in some warmer months (seasonal-continuous pattern, according to Pinheiro \& Fransozo, 2002). These data corroborate those obtained for another $C$. vittatus population by Turra \& Leite (2000). Seasonal reproduction is associated with environments characterized by wide variations in temperature or food availability (Giese, 1959). Temperature may act as a metabolic, biochemical and hormonal modulator, triggering the mechanisms of ecdysis, mating and gonad development. However, the availability of and/or competition for shells may influence reproductive activity and cause displacement of reproductive peaks and recruitment periods in coexisting populations (Turra \& Leite, 2000; Wada et al., 2000).

Finally, Turra \& Leite (2000) suggested that the occurrence of populations with seasonal reproductive patterns in the tropics and with continuous reproduction in temperate areas may be based on populations' evolutionary histories, although local factors should be considered. But a statistical analysis of a more exhaustive data set is required to elucidate any patterns in breeding peaks across latitudes (in both hemispheres), and comparative breeding records for congeners found over a wide range of latitudes should provide the best picture (Litulo \& Tudge, 2005).

\section{ACKNOWLEDGEMENTS}

Thanks to the biologist Cilene Mariane Zangrande for help in sampling and laboratory analyses in part of this study and to Dr Janet Reid for final English revision of the manuscript.

\section{REFERENCES}

Abrams P.A. (1988) Sexual difference in resource use in hermit crabs: consequences and causes. In Chelazzi G. and Vannini M. (eds) Behavioral adaptation to intertidal life. New York, USA: Plenum, pp. $283-296$.

Benvenuto C. and Gherardi F. (2001) Population structure and shell use in the hermit crab, Clibanarius erythrops: a comparison between Mediterranean and Atlantic shores. Journal of the Marine Biological Association of the United Kingdom 81, 77-84.

Bertini G. and Fransozo A. (2000) Population dynamics of Petrochirus diogenes (Crustacea; Anomura, Diogenidae) in the Ubatuba region, São Paulo, Brazil. In Klein von C. and Schram F. (eds) The biodiversity crisis and crustaceans. Rotterdam: A.A. Balkema, pp. 331-342.

Bertini G., Fransozo A. and Braga A.A. (2004) Ecological distribution and reproductive period of the crab Loxopagurus loxocheles (Anomura, Diogenidae) on the northern coast of São Paulo State, Brazil. Journal of Natural History 38, 2331-2334.
Branco J.O., Turra A. and Souto F.X. (2002) Population biology and growth of the hermit crab Dardanus insignis at Armação Itapocoroy, southern Brazil. Journal of the Marine Biological Association of the United Kingdom 82, 597-603.

Brossi-Garcia A.L. (1988) Juvenile development of Clibanarius vittatus (Bosc, 1802) Decapoda Anomura in the laboratory. Crustaceana 54, $294-313$.

Fotheringham N. (1975) Structure of seasonal migrations of the littoral hermit crab Clibanarius vittatus (Bosc, 1802). Journal of Experimental Marine Biology and Ecology 18, 47-53.

Fransozo A. and Mantelatto F.L.M. (1998) Population structure and reproductive period of the hermit crab Calcinus tibicen (Decapoda: Diogenidae) in the region of Ubatuba, São Paulo, Brazil. Journal of Crustacean Biology 18, 202-208.

Giese A.C. (1959) Comparative physiology: annual reproductive cycles of marine invertebrates. Annual Review of Physiology 21, 574-576.

Hazlett A.B., Rittschof D. and Bach C.E. (2005) The effects of shell size and coil orientation on reproduction in female hermit crabs, Clibanarius vittatus. Journal of Experimental Marine Biology and Ecology 323, 93-99.

Kicher A.B. (1967) The larval development of Clibanarius vittatus and Hypoconcha in six salinities. Master's thesis. Duke University, Durham, USA.

Litulo C. (2005a) Population structure and reproduction of the hermit crab Dardanus deformis (Anomura: Diogenidae) in the Indian Ocean. Journal of the Marine Biological Association of the United Kingdom 85, 883-887.

Litulo C. (2005b) Breeding of the hermit crab Dardanus deformis H. Milne-Edwards, 1836 (Anomura, Diogenidae) in Maputo Bay, southern Mozambique. Journal of Natural History 39, 2137-2144.

Litulo C. (2005c) Population biology and fecundity of the Indo-Pacific hermit crab Clibanarius longitarsus (Anomura: Diogenidae). Journal of the Marine Biological Association of the United Kingdom 85, $121-125$.

Litulo C. and Tudge C. (2005) Population structure and breeding season of the hermit crab Diogenes brevirostris Stimpson, 1858 (Decapoda, Anomura, Diogenidae) from southern Mozambique. Journal of Natural History 39, 2887-2889.

Lowery W.A. and Nelson W.G. (1988) Population ecology of the hermit crab Clibanarius vittatus (Decapoda: Diogenidae) at Sebastian Inlet, Florida. Journal of Crustacean Biology 8, 548-556.

Macpherson E. and Raventos N. (2004) Population structure and reproduction of three sympatric species of hermit crabs in the north-western Mediterranean. Journal of the Marine Biological Association of the United Kingdom 84, 371-376.

Manjón-Cabeza M.E. and Garcia-Raso J.E. (1995) Study of a population of Calcinus tubularis (Crustacea, Diogenidae) from a shallow Posidonia oceanica meadow. Cahiers de Biologie Marine 36, 277-284.

Manjón-Cabeza M.E. and García-Raso J.E. (1998) Population structure and growth of the hermit crab Diogenes pugilator (Decapoda: Anomura: Diogenidae) from the Northeastern Atlantic. Journal of Crustacean Biology 18, 753-762.

Manjón-Cabeza M.E. and Garcia-Raso J.E. (2000a) Morphological reproductive aspects of males of Diogenes pugilator (Roux, 1829) (Crustacea, Decapoda, Anomura) from southern Spain. Sarsia 85, 195-202.

Manjón-Cabeza M.E. and Garcia-Raso J.E. (200ob) Reproductive aspects of males of the hermit crab Diogenes pugilator (Crustacea: Decapoda: Anomura) from southern Spain. Journal of the Marine Biological Association of the United Kingdom 80, 85-93. 
Mantelatto F.L.M. and Garcia R.B. (1999) Reproductive potential of the hermit crab Calcinus tibicen (Anomura) from Ubatuba, São Paulo, Brazil. Journal of Crustacean Biology 19, 268-275.

Mantelatto F.L.M. and Martinelli M. (2001) Relative growth and sexual dimorphism of the south Atlantic hermit crab Loxopagurus loxochelis (Anomura, Diogenidae) from Ubatuba, Brazil. Journal of Natural History 35, 429-437.

Mantelatto F.L.M., Christofoletti R.A. and Valenti W.C. (2005) Population structure and growth of the hermit crab Pagurus brevidactylus (Anomura: Paguridae) from the northern cost of São Paulo, Brazil. Journal of the Marine Biological Association of the United Kingdom 85, 127-128.

Martinelli J.M., Mantelatto F.L.M. and Fransozo A. (2002) Population structure and breeding season of the South Atlantic hermit crab Loxopagarus loxochelis (Anomura, Diogenidae) from the Ubatuba region, Brazil. Crustaceana 75, 791-802.

Melo G.A.S. (1999) Manual de Identificação dos Crustacea Decapoda do Litoral Brasileiro: Anomura, Thalassinidae, Palinuridae, Astacidae. São Paulo: Editora Plêiade.

Negreiros-Fransozo M.L. and Fransozo A. (1992) Estrutura populacional e relação com a concha em Paguristes tortugae Schimitt, 1933 (Decapoda, Diogenidae), no litoral norte do Estado de São Paulo, Brasil. Naturalia 17, 31-42.

Negreiros-Fransozo M.L., Fransozo A., Mantelatto F.L.M., Nakagaki J.M. and Spilborgls M.C.F. (1992) Fecundity of Paguristes tortugae Schmitt, 1933 (Crustacea, Decapoda, Anomura) in Ubatuba (SP), Brazil. Revista Brasileira de Biologia 52, 547-553.

Pinheiro M.A.A. and Fransozo A. (2002) Reproduction of the speckled swimming crab Arenaeus cribrarius (Lamarck, 1818) (Brachyura Portunidae) on the Brazilian Coast near $23^{\circ} 30^{\prime}$ S. Journal of Crustacean Biology 22, 416-428.

Reigada A.L.D. and Santos S. (1997) Biologia e relação com a concha em Clibanarius vittatus (Bosc, 1802) (Crustacea, Diogenidae) em São Vicente, SP, Brasil. Brazilian Archives of Biology and Technology 40, 941-952.

Sant'Anna B.S., Zangrande C.M., Reigada A.L.D. and Pinheiro M.A.A. (2006) Shell utilization pattern of the hermit crab Clibanarius vittatus (Bosc, 1802) (Crustacea, Anomura), in an estuary at São Vicente, State of São Paulo, Brazil. Iheringia 96, 1-6.

Sant'Anna B.S., Christofoletti R.A., Zangrande C.M. and Reigada A.L.D. (2008) Growth of the hermit crab Clibanarius vittatus (Bosc, 1802) (Crustacea, Anomura, Diogenidae) at São Vicente, São Paulo, Brazil. Brazilian Archives of Biology and Technology 51, 547-550.
Sastry A.N. (1983) Ecological aspects of reproduction. In Watermam T.H. (ed.) The biology of crustacea. VIII environmental adaptations. New York: Academic Press, Inc., pp. 179-270.

Sokal R.R. and Rohlf F.J. (1995) Biometry. New York: W.H. Freeman and Company.

Squires H.J., Ennis G.P. and Dawe G. (2001) On biology of two sympatric species of hermit crab (Crustacea, Decapoda, Paguridae) at St Chads, Newfoundland. NAFO Science Council Studies 34, 7-17.

Sturges H.A. (1926) The choice of a class interval. Journal of the American Statistical Association 21, 65-66.

Turra A. (2004) Intersexuality in hermit crabs: reproductive role and fate of gonopores in intersex individuals. Journal of the Marine Biological Association of the United Kingdom 84, 757-759.

Turra A. and Leite F.P.P. (1999) Population structure and fecundity of the hermit crab Clibanarius antillensis Stimpson, 1862 (Anomura, Diogenidae) in Southeastern Brazil. Bulletin of Marine Science 64 , 281-289.

Turra A. and Leite F.P.P. (2000) Population biology and growth of three sympatric species of intertidal hermit crabs in south-eastern Brazil. Journal of the Marine Biological Association of the United Kingdom $80,1061-1069$.

Turra A. and Leite F.P.P. (2001) Shell utilization patterns of a tropical rocky intertidal hermit crab assemblage: I. the case of Grande Beach. Journal of Crustacean Biology 21, 393-406.

Young A.M. and Hazlett T.L. (1978) The effect of salinity and temperature on the development of Clibanarius vittatus (Bosc) (Crustacea: Decapoda: Diogenidae). Journal of Experimental Marine Biology and Ecology 34, 131-141.

Wada S., Kitaoka H. and Goshima S. (2000) Reproduction of the hermit crab Pagurus laguginosus and comparison of reproductive traits among sympatric species. Journal of Crustacean Biology 20, 474-478. and

Wenner A.M. (1972) Sex ratio as a function of size in marine crustacea. American Naturalist 106, 321-350.

\section{Correspondence should be addressed to:} B.S. Sant'Anna Research Group in Crustacean Biology (Crusta) Universidade Estadual Paulista (UNESP) Campus Experimental do Litoral Paulista (CLP) Praça Infante D. Henrique, s/n-Parque Bitarú CEP 11330-900-São Vicente (São Paulo), Brazil email: brunusant@hotmail.com 